\title{
ARSENIC CONTENT OF NAPOLEON I'S HAIR PROBABLY TAKEN IMMEDIATELY AFTER HIS DEATH
}

\author{
By Dr. STEN FORSHUFVUD, Dr. HAMILTON SMITH and Dr. ANDERS WASSÉN \\ Vasagatan 33, Göteborg C, Sweden, and Department of Forensic Medicine, \\ The University, Glasgow, W.2
}

$\mathrm{I}^{\mathrm{T}}$ has generally been deduced from the report of the post-mortem dissection dated St. Helena, May 6, 1821, and signed by the British medical officers, Thomas Shortt, Archibald Arnott, Charles Mitchell, Francis Burton and Matthew Livingstone, that Napoleon I's death the preceding day was due to extensive cancerous lesions of the stomach.

The view that Napoleon died of 'cancer' was not accepted by Franceseo Antommarohi, the man who actually performed the autopsy, who had been Napoleon's household physician for the last twenty months, and was the only physician on St. Helena with a pathologist's training. He maintained that the hepatitis the Emperor had suffered from for a long time was the cause of death. Furthermore, the Emperor's enlarged, tender liver, jaundiced complexion and yellow conjunctivæ had also been diagnosed as signs of severe hepatitis by Barry O'Meara, Napoleon's household physician during his first three years in exile, and John Stokoe, who had attended Napoleon for a week in January 1819.

Consequently, apart from Dr. Arnott, who assisted Antommarchi during the last few weeks when the morbid picture was especially baffling, those medical men who personally had attended Napoleon during his illness refused to admit that he had died from cancer.

Many medical writers with doubts about the cancer diagnosis have attempted to identify Napoleon's disease on St. Helena by analysing compilations of his signs and symptoms. This has produeed surprisingly disparate results. Thus, when exiled on St. Helena, Napoleon is alleged to have had, or suffered from the sequels of, the following diseases: peptic ulcer, intestinal ulceration, various liver inflammations, undulant fever, malaria, dysentery, rheumatoid arthritis, heart failure, congenital extremely slow blood circulation, epilepsy, tuberculosis, pleurisy, severe hormonal imbalance leading to obesity and impotence (dystrophia adiposogenitalis), syphilis, gonorrhcea, intoxication from defective teeth (socalled focal infection), gout, piles, and a constitutional predisposition to severe constipation which, it is said, was fatal owing to auto-intoxication and poisoning by laxatives.

If a suitable selection is made from the variety of signs and symptoms manifested by Napoleon on St. Helena, it is a simple matter to make out a con. vincing case for every one of these diagnoses in turn. But if what, after all, was a fairly unchanging disease pattern on St. Helena is taken as an entity, and allowance is made for all the signs and symptoms and their interrelations, then one cannot escape the impression that all the pieces form an orderly picture of two highly characteristic syndromes, namely, the chronic and acute types of arsenic poisoning.
Napoleon's condition was rather poor during the Hundred Days. However, his health improved while he was being taken into exile on board H.M.S. Northumberland; and Napoleon's general health remained good during the initial period on St. Helena when, with his sole companions and collaborators, the Chamberlain Las Cases and his son, he lived in a simple cottage on the estate, 'The Briars'.

Soon after moving to 'Longwood', which became his permanent residence, Napoleon's ailments again became manifest. He turned moody, had various aches and pains, the lower legs swelled up and would not carry him, exanthemata broke out, particularly on the legs, his sleep was abnormal with either insomnia or somnolence, diarrhœea and constipation alternated, headaches occurred with increasing frequency and severity.

His indispositions at first lasted only a few days at a time, his mental powers returning undiminished in the intervals. Nevertheless, members of his staff noticed marked changes in his expression and increasing difficulties in locomotion. Napoleon's legs were swollen and often collapsed under him.

On May 1, 1816, Napoleon had an attack lasting for a whole week. Las Cases mentions that he complained of weak legs, headache, hypersensitivity to light, and felt cold and shivery; his facial expression had changed markedly, he spoke sluggishly, and was morose and taciturn. Napoleon believed himself to have gout, suggesting that his feet were swollen and painful. Though Napoleon's teeth were perfectly sound, O'Meara recorded on June 16, 1816, that his patient had toothache. Later it turned out that the toothache was due to 'scurvy', that is, stomatitis. On July 26, 1816, Napoleon experienced the first stab of that pain in the hypochondrium which was a constant source of distress through the rest of his life. After a number of brief attacks of malaise, Napoleon fell ill for six weeks in succession on October 1, 1816. A troublesome cough was now added to the list of symptoms; he had pustules on the lips as well as in the oral cavity and throat. Napoleon was tormented by an insatiable thirst and had become perceptibly hard of hearing. Lassitude alternating with restlessness was a characteristic feature. $\mathrm{He}$ always felt cold and liked to sit near the fireplace. $\mathrm{He}$ could scarcely walk, because the swollen and weak legs would not carry him. The gums swelled up and the teeth became loose. Diffuse nausea with a predisposition for spasmodic vomiting without actual regurgitation of food were also noted. Napoleon had a relapse with the same manifestations as before on December 3 and 4, 1816, and his companions now became aware of his very jaundiced complexion. On December 14, 18 and 28 there were further attacks the symptoms of which included spastic involuntary 
movements and unconsciousness on several occasions. According to the head valet, Marchand, one of these bouts was combined with dysentery (that is, severe diarrhœa). For the first time in two months Napoleon went out of doors on January 26, 1817. Apart from brief indispositions in May, June and July, Napoleon's health seemed to remain comparatively good until September 25, 1817, when a period of illness set in which lasted approximately a whole year. The signs and symptoms were on the whole the same as before, but new features had been added. For example, in Dr. O'Meara's case notes for October 1817 , we read: on the third a swelling was palpable on the right side near the liver, on the ninth the pains in the legs and neighbourhood of the liver had inereased and pains in the shoulder supervened, on the eleventh the patient was seriously distressed by tachycardia. Afterwards severe constipation developed, the skin and conjunctivæ were yellow and the appetite was poor. The vomiting tendency was now accompanied by stomach-ache. The stomatitis was very distressing and on several occasions caused the cheeks to swell. Constant phenomena were 'febrile attacks' at nightfall and profuse sweating at daybreak. The tongue was coated, the pulse often very rapid and irregular.

Although Napoleon now had no physician in attendance - the British authorities had ordered O'Meara away from 'Longwood' on July 25, 1818 his health underwent a gradual improvement in the latter half of that year. Some symptoms nevertheless persisted for another few months, such as lancinating hypochondrial pains and painful and weak legs. Often the feet were ice cold and had to be warmed with hot towels, and the ex-Emperor frequently aat before the fire with his feet in a flannel bag.

In the final months of 1818 it seemed as though Napoleon was well on the way towards full recovery. Once more he began to take interest in his literary work and in his garden. He started taking regular exercise, a sign that his legs would support him again. In the beginning of November 1818 Bertrand, lo Grand-Marechal du Palais, wrote in his diary: ". . . le malheur a passé sur son caractère, comme sur un roc, sans l'abattre et sans y laisser de traces".

But Napoleon again became seriously ill towards the end of December 1818. The manifestations included tachycardia, chills, fever, and the old trouble from the legs. In the night between January 16 and 17,1819 , his life was threatened, he lost consciousness several times, and Dr. Stokoe was summoned. (He had been asked to become the Emperor's household physician the week before.) In his bulletins, Stokoe stated that he had found the patient in a state of extreme exhaustion, his com. plexion was yellow and he had pains in the region of the liver and in the shoulder. There was excruciating headache, vertigo and fainting fits. Some improvement took place when the patient began to sweat profusely. Similar attacks recurred the next night and the next night but one. Stokoe issued three bulletins about Napoleon's health, and these so displeased the Governor, Sir Hudson Lowe, that Stokoe was constrained to leave St. Helena. So on January 22, 1819, Napoleon again found himself without a physician. His health nevertheless improved, and in the latter half of 1819 he was busily at work every morning from 4 a.m. to 10 a.m. supervising the extensive landscaping projects he was undertaking in his garden. He could now walk with a stick, had recovered his former good temper, and conversed pleasantly and cheerfully with his companions. Apart from a few brief indispositions, this state of good health lasted for fifteen months.

However, a new long period of uninterrupted illhealth commenced on September 18, 1820. This period was marked by at least six intercurrent attacks of violent illness with severe and acute symptoms, but during the intervals of remission Napoleon's health improved day by day even though some of the symptoms persisted. During these periods of convalescence he could be up and about and also, albeit with tottering steps, go for short strolls in the garden.

According to Dr. Antommarchi's case notes, the acute attacks were accompanied by the following symptoms: headache; dyspncea; weak, rapid and irregular pulse; ice-cold feet and legs; gastric pains; loss of appetite; somnolence that seemed refractory to treatment; yellow conjunctivæ; yellow complexion; excessive paleness; dark rings under the eyes; coated tongue; burning thirst; tachycardia; tremor; nervous dry cough; vertigo; vomiting; sensation of heat in the viscera; pain in the legs and from the liver, sternum and shoulder regions; constipation and diarrhoea; spasmodic contractions of triceps; remarkably weak legs; restlessness; nightmares; exanthemata; loose teeth; bleeding gums; insomnia; hardness of hearing; extreme hypersensitivity to light; impaired vision; very severe general exhaustion.

On March 22, 1821, Napoleon's disease changed character, with constant severe vomiting supervening. This was doubtless because he had been prescribed and--without knowing it-taken tartar emetic. Accordingly, antimony poisoning was now an added complication. A remission lasting for two and a half weeks occurred in the beginning of April 1821, and Napoleon took this opportunity to write his last will and testament.

Late at night on April 24, 1821, there was a severe relapse with typical manifestations of acute antimony poisoning. Additional relapses occurred over the next few days. However, a moderate improvement seems to have taken place on May 3 . In the afternoon of that day Napoleon unknowingly took a large dose of calomel. Thirty minutes before midnight he had copious stools with the appearance of tar. Additional evacuations of blood occurred on May 4. He died on May 5, 1821, after lying absolutely motionless for approximately $24 \mathrm{hr}$.

At the post-mortem examination the stomach was full of black blood and the gastric mucosa was very badly corroded. These findings were probably sequels of the calomel given on May 3 rather than of arsenic. On the other hand, the following signs of arsenic poisoning were encountered: enlarged and hardened liver, enlarged spleen, fluid effusions in the pleuræ, bronchial and mediastinal lymph nodes degenerated and in suppuration, loss of all body hair, large fat deposits under the skin and in the abdomen.

Napoleon was not embalmed. Yet, when his coffin was opened in 1840, those present were astonished at finding him extremely well preserved.

In the light of the foregoing, it seems that on St. Helena Napoleon suffered from chronic arsenic poisoning with intervening periods of acute arsenic poisoning. In such circumstances, we deemed it interesting to apply the activation technique in a study of Napoleon's hairs from the period on St. 
Helena. Through the courtesy of M. le Commandant Henry Lachouque, the great French expert on Napoleon's life and the organizer of the permanent Napoleonic exhibitions on St. Helena and in the French Army Museum, hair taken from Emperor Napoleon I's head, probably on the day after his death, has been made available to us.

The hair sample thus obtained was sent to the Department of Forensie Medicine at the University of Glasgow, where it was examined using an activation analysis technique (Smith, 1959) as follows.

The hair sample was weighed $(1.72 \mathrm{mgm}$.) and sealed in a polythene container. It and a standard arsenic solution sealed in a silica ampoule were irradiated by thermal neutrons for one day at $10^{12}$ neutrons $/ \mathrm{cm} .{ }^{2} / \mathrm{sec}$. in a nuclear reactor at the Atomic Energy Research Establishment, Harwell. There. after the sample was returned and the arsenic extracted with added carrier arsenic by a modified Gutzeit technique. The activity from the hair sample was compared with that from the standard arsenic sample and the arsenic content of the hair was calculated.

The value found for the sample of hair was $10 \cdot 38$ parts per million. This is high by comparison with the normal mean arsenic content of about 0.8 p.p.m. Unfortunately, it was not possible to make any distribution studies as no further hair samples were available. It is impossible to tell from the value alone whether the arsenic was evenly distributed (as expected in continuous exposure) or located in one point (as would be the case in a single large exposure).

This investigation shows the great advantage of activation analysis when only very small quantities of sample are available.
BIBLIOGRAPHY

Antommarchi, F., Les derniers momens de Napolén (Paris, 1825). Arnott, A., An Account of the Last Illness, etc. (London, 1822). Beckmann, K., "Krankheiten der Leber", in Handbuch der inneren Medizin, 3, 2 (1953).

Bertrand, H.-G., Cahiers de Sainte-Hélène (Paris, 1949, 1951, 1959).

Boutron et al., Annales d'Hyg. pub. et Méd. leg., 25, 11 (1841).

Cabanès, Au chevet de l'Empereur (Paris, 1924).

Cabanès and Nass, Poisons et Sortilèges (Paris, 1903).

Douris, R., Toxicologie moderne (Paris, 1951).

Forshufvud, S., Le drame de Poison a Sainte-Hélene (Plon, Paris, 1961; in the press)

Forsyth, W., History of the Captivity, etc. (London, 1853).

Funck-Brentano, F., Le drame des poisons (Paris, 1920).

Gigon, A., "Krankheiten der Mundschleimhaut", in Handbuch der inneren Medizin, 3, 1 (1953).

Gonnard, Ph., Lettres du Comte et la Comtesse de Montholon, 1812 1821 (Paris, 1906).

Gourgaud, G., Journal de Sainte-Helene (Paris, 1947).

Gril, E., La Marquise de Brinvilliers Empoisonneuse (Paris, 1933).

Hansen, F., and Møller, K., Acta pharm., 5, 135 (1949).

Heffter, A., Deutsch. med. Wschr., 47, 853 (1921).

Kalima, T., Acta chir, scand., 72,1 (1932).

Kemble, J., Napoleon Immortal (London, 1959).

Kratter, J., Lehrbuch der gerichtlichen Medizin (Stuttgart, 1912).

Las Cases, E., Mémorial de Sainte-Helène (Paris, 1823).

Liebegott, G., Deutsch. med. Wschr., 74, 855 (1949).

McNally, W. J. Amer, Chem. Assoc., 39, 826 (1917).

Marchand, L., Mémoires de Marchand, 2 (Lachouque, Paris, 1955).

Mayers, M., Arch. Indust. Hyg., 9, 388 (1954).

Merkel, H., "Die Magenverätzungen", in Handbuch der spez. path. Anatomie $u$. Histologie (Henke and Lubarsch, Berlin, 1926).

Montholon, Ch., Histoire de la Captivité, ete. (Leipzig, 1846).

Munch-Pedersen, C. J., "Polyneuritis", in Nord. lärobok $i$ internaed, 5 (1958).

Nass, L., Les empoisonnements sous Louis XIV (Paris, 1898).

O'Meara, B., Napoleon in Exile (London, 1822).

Petri, E., "Path. Anatomie und Histologie der Vergiftungen", in Handbuch der spez. path. Anat. u. Hist. (Henke and Lubarseh, Berlin, 1930).

Saint-Denis, L., Souvenirs du Mameluck Ali sur l'Empereur Napoleon (Paris, 1926).

Smith, H., Anal. Chem., 31, 1361 (1959).

Watjen, J., Virchows Arch. path. Anat. u. Phys., 256, 85 (1925).

\section{TEACHING MACHINES}

Co many members were interested in the sym$S$ posium on "Teaching Machines" in Section $J$ (Psychology) at the British Association meeting at Norwich on September 4 that the 'house-full' notice had to be used. Introducing the subject, the chairman, Prof. H. Kay, pointed out the theoretical and practical implications of teaching machines. It is likely that their use in research will contribute considerably to our understanding of learning processes. Psychologists recognize that hitherto they have carried out extensive experiments on animal behaviour but have neglected the study of human learning. Here is a definite opportunity to examine in ideally controlled conditions the variables which are influencing learning. On the practical side there is not only a desperate national need for teachers, particularly in science subjects, but also an increasing problem of how to impart technological information on a worldwide scale. The urgent need is for new forms of communication; teaching machines represent one such form.

Dr. J. Annett, of the Department of Psychology, University of Sheffield, outlined the main requirements for a teaching machine. It is a device not only for imparting information but also for sensing that this information has been received and understood. It is a two-way communication channel designed at every stage to check the progress of the student and, ideally, to modify its instructions on the basis of the students' responses. This may be achieved by several methods. Perhaps the simplest is the small step or linear-type programming developed by Prof. Skinner at Harvard, where a series of statements and questions are built up and are repeatedly modified on the basis of the actual success of students in mastering them. Eventually a sequence is established so that when this programme is presented to other students nearly all the problems of subject-matter presentation have been anticipated. Such a programme is time-consuming to prepare, is lengthy in so far as there are many items with short steps between them, but is efficient and requires little use of 'gadgets' for presentation.

An alternative system is known as intrinsic programming. Here there is a main line of communication, and provided a student can respond correctly he can proceed smoothly along this route. But if he makes a mistake he is directed to a branch line, where further explanations are given before returning him to the main sequence. Dr. Annett explained that in the type of machine constructed at the Department at Sheffield this system had been achieved by a sequence of ' $A$ ' frames and ' $B$ ' frames. If any one of the ' $A$ ' frames is misunderstood, a ' $B$ ' frame is selected and the point is explained in greater detail. This type of machine is flexible enough to cope with students differing considerably in intellectual ability. A machine might operate on a 